\title{
FAKTOR PERCERAIAN SUAMI PERANTAU DALAM PERSPEKTIF HUKUM KELUARGA
}

\author{
(Studi Kasus di Kecamatan Sawit Seberang Kabupaten Langkat)
}

\author{
Rasyidin \\ Institut Agama Islam Negeri Langsa \\ rasyidin@iainlangsa.ac.id \\ Mayang Diwana \\ Institut Agama Islam Negeri Langsa \\ mayangdiwana72@gmail.com
}

\begin{abstract}
In Islam divorce is something that is not prohibited but is an act that is hated by Allah SWT. In Islam itself, the law of divorce is makhruh. Especially in the Sawit Seberang community, divorce has occurred a lot, especially for migrant workers, so that a divorce that occurs in the community is no longer an unusual thing, because there are many factors that trigger divorce in the household. The purpose of this study is to find out what is the biggest factor that triggers so many divorce cases among the community, especially the Sawit Seberang community from among the husbands of immigrants. This research method uses qualitative research methods (field research). The primary data sources were obtained through observation and interviews with the community and the parties concerned who clearly knew about the divorce case. based on the results of research that has been carried out by the author, the author concludes that the dominant factor in the occurrence of divorce among nomad husbands in Sawit Seberang District is the infidelity factor. It can be concluded that the existence of a third party is something that is very influential in household resilience, and this often happens, especially in the Sawit Seberang community.
\end{abstract}

Keywords: Divorce, Factors, Nomads

\begin{abstract}
Abstrak
Dalam Islam perceraian adalah sesuatu yang tidak dilarang akan tetapi suatu perbuatan yang dibenci oleh Allah SWT. Dalam Islam sendiri hukum perceraian ini hukumnya makhruh. Terutama dalam masyarakat Sawit Seberang perceraian sudah banyak terjadi terutama pada pekerja perantau, sehingga sebuah perceraian yang terjadi di kalangan masyarakat bukan lagi suatu hal yang tidak biasa, karena banyaknya faktor yang memicu terjadinya perceraian didalam rumah tangga. Adapun tujuan dari penelitian ini yakni untuk mengetahui faktor terbesar apa yang memicu sehingga banyaknya kasus perceraian di kalangan
\end{abstract}


masyarakat terutama masyarakat Sawit Seberang dari kalangan suami perantau. Metode penelitian ini menggunakan metode penelitian kualitatif (penelitian lapangan). Adapun sumber data primer yang diperoleh melalui observasi dan wawancara bersama masyarakat maupun pihak yang bersangkutan yang mengetahui secara jelas atas kasus perceraian tersebut. berdasarkan hasil penelitian yang telah dilakukan oleh penulis, penulis mendapatkan kesimpulan bahwa faktor yang mendominan terjadinya perceraian dikalangan suami perantau di Kecamatan Sawit Seberang yakni karna faktor perselingkuhan. Hal ini dapat penulis simpulkan bahwa adanya pihak ketiga adalah suatu hal yang sangat berpengaruh dalam ketahanan rumah tangga, dan hal ini sering terjadi terutama di masyarakat Sawit Seberang.

Kata kunci: Perceraian, Faktor, Perantau

\section{Pendahuluan}

Dalam kehidupan rumah tangga yang awalnya suami istri saling mencintai dan menyayangi seolah olah semuanya tidak akan pudar, pada kenyataannya semua itu bisa hilang apabila sebuah rasa dan kasih sayang itu tidak di jaga bahkan mengakibatkan bisa putusnya suatu ikatan bahtera rumah tangga. Jika kebencian dan perasaan sudah hilang dan tidak ada yang berusaha untuk mempertahankannya maka bisa berakibatkan berpisah atau bercerai. ${ }^{1}$

Rumah tangga yang harmonis dapat tercapai apabila ada prinsip bahwa pernikahan itu adalah suatu ikatan seumur hidup dan selamanya, hanya maut yang dapat memisahkan sebuah hubungan yang suci ini, bukan hanya sebuah janji yang memiliki tenggat waktu yang dapat di putuskan begitu saja dengan mudah, itulah sebuah prinsip yang harus di tanamkan di dalam hati bahwa pernikahan dalah sesuatu yang harus dan patut di pertahankan ${ }^{2}$. Sehingga perkawinan tidah mudah di permainkan dan mudah di putus begitu saja, sebagaimana yang sudah di ajarkan oleh syari'at islam itu sendiri.

Syariat Islam mengartikan sebuah pernikahan adalah sebuah hubungan suci dan kokoh, sebuah ikatan pernikahan itu sangat kokoh yang tidak pantas untuk di rusak maupun di anggap sepele, karena Allah sangat membeci kepada orangorang yang menganggap sepele sebuah hubungan pernikahan apalagi merusaknya, karena hubungan pernikahan adalah janji suci dan ikatan yang sakral sehingga Allah sangat membeci suatu tindakan yang menimbulkan kerusakan dalam sebuah hubungan pernikahan, karena sifat tersebut dapat merusak rumah tangga dan kemaslahatan suami istri itu sendiri.

Maka dari itu suatu hubungan harus di pertahankan dari kedua belah pihak, baik istri mapun suami wajib memelihara keutuhan rumah tangga mereka, dan mempertahankannya, tidak sepantasnya suami istri tersebut sengaja merusak sebuah hubungan dalam pernikahan mereka, walaupun dalam islam seorang suami di berikan hak untuk menjatuhkan talak kepada istri jika pernikahan tersebut sudah tidak harmonis lagi, dan istri juga di bolehkan untuk mengajuka gugatan cerai ke pengadilan apabila dalam pernikaha istri merasa tidak di berlakuan dengan adil, akan tetapi keduanya tidak sepatutnya di gunakan dengan

${ }^{1}$ Satria Efendi, Problematika Hukum Keluarga Islam Kontenporer (Jakarta: Kencana, 2004).97

${ }^{2}$ Abdul Rahman Ghazali, Fiqh munakahat (Cet. Ke- 3, Jakarta: Kencana, 2008).22 
gegabah atau dengan alasan bahwa islam memperbolehan suami menalak istri lalu suami merasa berhak dan menganggap sepele sebuah hubungan pernikahan hanya karena hawa nafsunya. ${ }^{3}$

Dalam kehidupan masyarakat Sawit Seberang Langkat sebgai observasi awal peneliti, diketahui bahwa mayoritas pekerjaan penduduknya bertani, dan merantau. ${ }^{4}$ Faktor ekonomi menjadi salah satu yang mengharuskan mereka untuk pergi jauh mencari nafkah untuk keluarganya di rumah. Akan tetapi fenomena ini malah menjadi sebuah masalah dalam rumah tangga itu sendiri, terlalu lamanya suami meninggalkan rumah membuat istri mengambil kesempatan untuk berselingkuh atau sebaliknya. Hal ini menjadi bomerang bagi rumah tangga itu sendiri yang pada akhirnya pernikahan berakhir di pengadilan.

Kasus perceraian sudah sering terjadi di masyarakat Sawit Seberang Langkat, sebagaimana hasil dari wawancara kepada karyawan KUA Sawit Seberang tentang permasalahan dan alasan perceraian. Beliau mengatakan bahwa perceraian sering terjadi dikarnakan faktor perselingkuhan, sudah tidak adanya lagi kecocokan, dan faktor ekonomi. Mungkin banyak lagi faktor yang lain akan tetapi faktor tersebut yang paling mendominasi. ${ }^{5}$

\section{Perkawinan dalam Masyarakat Aceh}

Perkawinan merupakan kebutuhan dharuri manusia untuk memelihara dan menjaga keturunan. Dari perkawinan tersebut melahirkan hak dan kewajiban antara mereka sesuai dengan hukum syara`. Sering dipahami bahwa, kewajiban suami dalam kehidupan rumah tangga adalah memberi nafkah kepada anak dan isteri. Seiring perkembangan zaman, pemahaman ini telah terjadi pergeseran nilai, yakni isteri tidak menutup kemungkinan bekerja untuk membantu suami dalam memenuhi kebutuhan rumah tangga.

Pada dasarnya hal seperti ini telah menjadi budaya dalam masyarakat Aceh, khususnya yang berdomisili di pedesaan. Misalnya suami bercocok tanam dan isteri menanam padi. Isteri beraktifitas dalam lingkaran domestik di rumah, sementara suami mencari nafkah di tempat yang lain, namun tugas rumah tetap menjadi prioritas isteri. Dari hasil aktifitas tersebut mereka telah memperoleh harta sesuai dengan pekerjaan masing-masing.

Dalam perspektif kajian pemikiran keislaman, terutama fiqih klasik dari sejumlah litelatur belum membahas tentang aktifitas dan rutinitas pekerjaan rumah seperti memasak, mencuci merupakan bagian dari kewajiban isteri, sementara perspektif budaya dan adat istiadat telah menjadikan kegiatan domestik ini bagian dari kewajiban isteri. Mayorias ulama tradisional (Dayah) Aceh dalam hal ini berpendapat, pekerjaan domestik tersebut harus diberikan upah. Fenomena di Aceh seluruh suami tidak memberikan upah atau gaji kepada mereka. ${ }^{6}$

Responsitas adat terhadap persoalan tersebut dilatar belakangi oleh

\footnotetext{
${ }^{3}$ Abdul Rahman Ghazali, Fiqh munakahat.21

${ }^{4}$ Sebagian besar masyarakat merantau ke Padang, Riau, Aceh, Jawa, Malaysia dan Jepang, dan meninggalkan istri dan keluarga dalam kurun waktu 4 bulan sampai 2 tahun lamanya.

${ }^{5}$ Sudariadi, Wawancara Karyawan KUA Sawit Seberang, 11 November 2020.

${ }^{6}$ Abu Mustafa Paloh Gadeng, Wawancara Ketua Majelis Permusywaratan Ulama Kabupaten Aceh Utara, 20 September 2016.
} 
pandangan isteri pada umumnya ketika telah melangsungkan pernikahan, mereka menyerahkan seluruh jiwa raganya untuk melayani dan berbakti kepada suami dan mendidik anak-anaknya. Bias dari pemikiran ini lama kelamaan melekat dalam jiwa masyarakat bahwa, pekerjaan domestik menjadi suatu keharusan bagi isteri.

\section{Talak Menurut Fiqh}

Perkawinan yang telah terpenuhi unsur-unsur baik rukun maupun syaratsyarat, unsur lahiriyah maupun batiniyah maka hubungan perkawinannya akan berlangsung sampai mereka kembali kepada Allah. Namun bila sebuah perkawinan tidak terpenuhi hal-hal tersebut maka akan timbul perceraian atau talak. Islam sangat membenci perceraian yaitu cerai hidup sekalipun itu perbuatan halal. Tetapi sebagai jalan terakhir bagi suami dan isteri agar tidak berlarut-larut dalam persengketaan dan perselisihan yang tidak dapat diselesaikan antara kedua belah pihak maka solusi terbaik yang ditawarkan agama adalah perceraian, sekalipun pada dasarnya semua pihak tidak menginginkan adanya perceraian

Perceraian atau cerai dalam kajian fiqih disebut dengan al-thalaq, secara etimologis artinya melepaskan ikatan. ${ }^{7}$ Ungakapan thaliq adalah ditujukan kepada unta yang tali kekangnya telah diurai dan dilepaskan di tempat penggembalaan. Ungkapan atlaqta al-asir artinya kamu melepaskan tawanan. ${ }^{8}$ Ibnu Manzur berkata, Menalak wanita memiliki dua arti. Salah satunya, menguraikan ikatan pernikahan. Dan yang lain berarti membebaskan dan melepaskan. Jika seseorang dimerdekakan, maka dia dinamakan thaliq. Artinya, dia menjadi orang merdeka. Dikatakan: dia taliq, taliq, taliq, dan mutallaq, jika dia dibebaskan. Dan taliq artinya membebaskan, melepaskan dan menguraikan. ${ }^{9}$

Dalam bahasa Indonesia kata "talak" adalah perceraian antara suami dan isteri; lepasnya ikatan perkawinan. Menalak berarti menceraikan isteri; atau menjatuhkan talak. Sedangkan ungkapan "cerai" adalah pisah; berhenti berlaki bini, putus pertalian, menyapih; perpecahan, perpisahan. ${ }^{10}$ Ungkapan "talak" secara terminologis sebagai didefinisikan Zakariya al-Anshari dalam kitab Fath alWahhab adalah:

$$
\text { الطلاق.هو لغة حل القيد وشر عا حل عقد النكاح بلفظ الطلاق ونحوه110 }
$$

"Talak menurut bahasa adalah melepaskan ikatan. Dan talak menurut syar ${ }^{i}$ yaitu melepaskan ikatan nikah dengan menggunakan ucapan talak atau semisalnya."

Ungkapan yang sama mengenai definisi talak ini diutarakan oleh al-Khatib alSyarbaini dalam kitabnya Mughni al-Muhtaj:

\footnotetext{
${ }^{7}$ Al-Sayyid al-Bakry Muhammad Syatha al-Dimyathy, I'anat al-Talibin, Jilid. IV, (Semarang: Toha Putra Semarang, tt).2

8Yahya Abd a-Rahman al-Khatib, Ahkam al-Mar'ah al-Hamil fi al-Syariah al-Islamiyah, terj. Mujahidin Muhayan (Jakarta: Qisthi Press, 2009).152-152

${ }^{9}$ Ibnu Manzur, Lisan al- 'Arab, Jilid.X, (Beirut: Dar Sadir, 1990).229

${ }^{10}$ Uswatun K, Kamus Bahasa Indonesia Lengkap (Jakarta: Kimberly, 2014).143

11Zakariya al-Anshari, Fath al-Wahhab bi Syarh Minhaj al-Thulab, Jilid. 2 (Beirut: Dar al-Fikr, 1414

H/1994 M). 87
} 


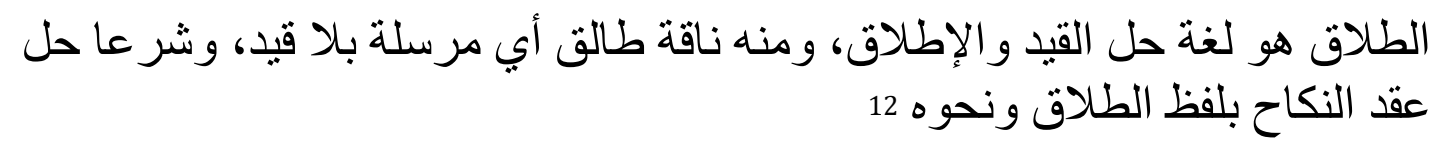

"Al-talaq menurut bahasa melepaskan ikatan dan bebas, sebagaimana ungkapan "menjadi bebas tanpa ikatan. Al-talaq menurut syara' lepasnya ikatan nikah karena menggunakan ucapan talak dan sejenisnya."

Bakri Muhammad Syatha menambahkan definisi talak yang sedikit lebih rinci mengenai batasan ucapan yang dipakai untuk talak yaitu: thalaq, firaq, sirah dan sejenisnya. ${ }^{13}$

Melihat dari kronologis kehidupan rumah tangga, fiqih mengkategorikan talak ini ke dalam beberapa kategori yaitu: Pertama, adakalanya menjadi wajib seperti talak suami yang meng-ila` isterinya dengan tidak ingin mencampuri isterinya. Kedua, talak menjadi hukum sunat sebagaimana seorang suami tidak sanggup lagi memenuhi nafkah lahir dan batin, atau isteri berkelakuan buruk, dan melanggar perintah-perintah Allah, atau melakukan larangan-larangan-Nya sehingga sulit untuk memperbaikinya. Artinya secara adat dan uruf suami sulit bergaul lagi dengan isterinya. Ketiga, talak hukumnya haram seperti talak bid`i yaitu talak isteri dalam keadaan haidh atau suci yang telah digauli, talak suami yang sakit sekarat dengan tujuan agar isterinya tidak mendapatkan hak warisan.14 Keempat, makruh yaitu talak bukan berdasarkan alasan-alasan tersebut di atas. Dengan kata lain hukum dasar talak adalah makruh

\section{Hukum Menjatuhkan Talak}

Menjatuhan talak tanpa sebab dan alasan yang jelas adalah sebuah perbuatan yang tercela dan juga sebuah perbuatan yang sangat di benci oleh Allah. Di balik sesuatu yang halal ada hal yang di murkai oleh Allah apabila di gunakan dengan tidak sebaik- baiknya apalagi dengan nafsu dan keegoisan diri sendiri, sesuatu perbuatan yang Allah SWT murkai pelakunya tanpa sebab yang jelas adalah perbuatan menjatuhkan talak.

Maka dari itu perbuatan menjatuhkan talak adalah sesuatu perbuatan yang tidak membuahkan pahala dan di pandang sebagai berbuatann yang bukan ibadah. menjauhkan diri dari perbuatan talak tersebut lebih bagus selagi masih ada jalan untuk memperbaiki hubungann tersebut, akan tetapi suami berhak menjatuhkan talak tersebut apabila sudah tidak ada jalan keluar lagi unntuk permasalahan tersebut, dan apabila di pertahankan akan timbulnya kemudharatan bagi suami ataupun istri..$^{15}$ Ulama Hanabila (penganut mazhab Hambali) memperinci hukum talak sebagai berikut:

a. Talak ada kalanya wajib, kadang- kadang haram, mubah, dan kadangkadang dihukumi sunnah. Talak wajib yakni talak yang terjadi akibat

\footnotetext{
12Muhammad Khatib al-Syarbini, Mughni al-Muhtaj, Jilid. IV (Beirut: Dar al-Kutub al-'Ilmiyah, 1994).455

13 Al-Sayyid al-Bakry Muhammad Syatha al-Dimyathy, I'anat al-Talibin.3

${ }^{14}$ Al-Sayyid al-Bakry Muhammad Syatha al-Dimyathy, I'anat al-Talibin.7

15 Abdul Rahman Ghazali, Fiqh munakahat.212-213
} 
perselihian suami istri yang sudah tidak bias lagi di selesaikan dan tidak dapat di damaikan, sehingga kedua belah pihak memandang perceraian adalah jalan untuk menyelesaikan persengketaan di antara meraka.

b. Adapun talak yang di haramkan yakni, talak yang tidak di perlukan dan merugikan suami ataupun istri, yang mana talak ini di lakukan tanpa alasan yang jelas.

c. Talak mubah terjadi hanya apabila di perlukan, misalnya karena istri tidak terlihat menarik, sikapnya buruk dan gaya hidup yang buruk, sehingga tidak ada harapan adanya kebaikan pada istri.

d. Talak mandub atau talak sunnah yakni talak yang di lakukan kepada istri yang sudah keterlaluan dan sudah tidak bisa lagi untuk di nasehati untuk kebaikan, dan tidak mempunyai sikap yang sopan dan selalu melanggar perintah Allah seperti meninggalkan shalat. ${ }^{16}$

Talak menurut Pasal 117 Kompilasi Hukum Islam adalah ikrar suami di hadapan pengadilan Agama yang menjadi salah satu sebab putusnya perkawinan. Adapun hal- hal yang apat di jadikan untuk melakukan perceraian di jelaskan dalam pasal 39 ayat (2) Undang- undang Nomor 1 tahun 1974 tentang perkawinan yakni: ${ }^{17}$

1. Satu pihak melakukan zina, ${ }^{18}$ penjudi ataupun seorang pemabuk.

2. Salah satu pihak meninnggalkan pihak lain selama 2 tahun berturut- turut tanpa izin dari pihak yang lain.

3. Salah satu pihak mendapat hukuman penjara selama 5 tahun ataupun hukuman yang berat setelah pernikahan.

4. Salah satu pihak melakukan tindak kekerasan dalam rumah tangga.

5. Salah satu pihak memiliki kecacatan ataupun suatu penyakit yang mana tidak dapat menjalankan kewajibannya sebagai suammi ataupun istri.

6. Dalam kehidupan rumah tangga selalu terjadi perselisihan dan pertengkaran yang sudah tidak menjamin keluarga akan rukun kembali.

Dari keterangan di atas dapat di simpulkan bahwa faktor dominan yang menjadi alasan adalah :

1. Zina

2. Satu pihak meninggalkan pihak lain selama 2 tahun berturut- turut tanpa izin pihak yang lain

3. Satu pihak mendapat hukuman penjara selama 5 tahun

4. Tindak kekerasan dalam rumah tangga

5. Karena cacat atau penyakit

6. Sering terjadi perselisihan

Talak memiliki rukun yakni Qashdu (kesengajaan) dalam talak tersebut berunsur kesengajaan, yakni sengaja akan terjadinya talak dan sudah di rencanakan akan menjatuhkan talak tersebut, yang mana talak itu di harapkan

\footnotetext{
16Tihami \& Sohari Sahrani, Fiqih Munakahat (Jakarta: PT Raja Grafindo Persada, 2009).250

${ }^{17}$ Abdurrahman, Kompilasi Hukum Islam, (Jakarta: CV Akademika Presissindo, 2015).76

${ }^{18}$ Zina dalam Kamus Besar Bahasa Indonesia adalah perbuatan bersenggama antara laki- laki dan perempuan yang tidak terikat oleh hubungan pernikahan (perkawinan)
} 
benar- benar terlaksana dan di harapkan, yaitu talak yang di lafalkan dan dengan redaksi sharih. Talak yang di ucapkan oleh orang yang tidur, orang yang tidak sengaja mengatakan talak, di paksa dan orang yang tidak memahami hukum talak itu sendiri, talaknya tidak sah. Talak yang di ucapkan oleh orang yang di paksa tanpa alasan apapun talaknya tidak sah. ${ }^{19}$

Pada prinsipnya tujuan pernikahan yakni membentuk suatu keluarga, di mana dalam suatu hubungan keluarga harus ada rasa percaya terhadap pasangan dan komitmen dari keduanya, akan tetapi banyak konflik yang terjadi setelah terjalinnya suatu bahtera rumah tangga, banyak pasangan yang mengalami gejolak dalam rumah tangganya, seperti pereslisihan yang tidak ada habisnya hingga pertengkaran yang sering terjadi tanpa adanya jalan keluar, maka dari itu banyak keluarga atau pasangan yang memilih untuk mengakhiri hubungan pernikahan mereka dengan kata lain yakni bercerai. ${ }^{20}$

\section{Jenis dan Pembagian Talak}

Secara bahasa, kata perceraian berarti melepas ikatan. Sedangkan dari bahasa arab yakni اطلاق yang artinya lepasnya suatu ikatan perkawinan dan berakhirnya hubungan perkawinan. Menurut istilah syarak talak adalah melepas tali perkawinan dan mengakhiri hubungan suami istri. ${ }^{21}$ Menurut Azhar Ahmad dalam bukunya beliau menjelaskan arti talak ialah menghilangkan ikatan perkawinan atau mengurangi pelepasan ikatannya dengan menggunakan kata tertentu, sedangkan menurut Abu Zakariya Al- Ansari talak yakni melepas tali akad nikah dengan kata talak dan semacamnya.22

Banyak pendapat tentang bagaimana pengertian dari talak, akan tetapi pada intinya talak yakni menghilangkan suatu ikatan perkawinan sehingga setelah hilangnya ikatan perkawinan itu istri tidak lagi halal bagi suaminya. Walapun talak dibenci oleh Allah SWT akan tetapi masih banyak rumah tangga yang pecah dan memutuskan untuk bercerai. Dalam pasal 1 Undang- undang No. 1 Tahun 1974 menegaskan:

"Perkawinan ialah ikatan lahir batin antara seorang pria dan seorang wanita sebagai suami istri dengan tujuan membentuk keluarga (rumah tangga) yang berbahagia dan kekal berdasarkan Ketuhanan Yang Maha Esa."23

Suami istri perlu saling memiliki rasa percaya, saling membantu dalam keadaan susah maupun senang dan saling mengerti kepribadian masing- masing agar terciptanya keluarga yang harmonis dan sejahtera, yang mana dalam Undangundang ini menjelaskan bahwa perceraian bukanlah hal yang diinginkan dalam sebuah rumah tangga, dengan kata lain Undang- undang ini mengsukarkan suatu perceraian. Perceraian bisa dilakukan jika memiliki alasan- alasan tertentun dan jelas yang menyebabkan tidak adanya lagi alasan untuk mempertahankan suatu ikatan rumah tangga tersebut, dan perceraian hanya bisa dilakukam didepan sidang pengadilan. ${ }^{24}$

\footnotetext{
${ }^{19}$ Wahbah Zuhaili, Fiqih imam syafi'I jilid II, (Jakarta: Almahira, 2010). 589

${ }^{20}$ Slamet Abidin dan Aminuddin, Fiqh Munakahat 2 (Bandung :Pustaka Setia, 1999).73

${ }^{21}$ Azhar Ahmad, Hukum Perkawinan Islam (Yogyakarta: UII Press,2004).192

${ }^{22}$ Azhar Ahmad, Hukum Perkawinan Islam.193

23Undang- undang No. 1 Tahun 1974 Tentang Pernikahan

${ }^{24}$ Sajuti Thalib, Hukum Kekeluargaan Indonesia, cet.4 (Jakarta: UI- Press, 1986).94
} 
Talak diperbolehkan sebagai alternatif terakhir dari sebuah hubungan keluarga, yang mana islam juga menunjukkan cara ataupun jalan keluar dari sebuah pertengkarang yang ada didalam rumah tangga, yang mana sebelum terjadinya perceraian adanya usaha- usaha yang dilakukan untuk menemukan jalan perdamaian antara kedua belah pihak, baik melalui nasihat, hakam (arbitrator) dari kedua belah pihak, atau melalui langkah- langkah yang lainnya. ${ }^{25}$

Suami yang menceraiakn istrinya disebut dengan talak. Sebaliknya apabila istri yang menggugat cerai suaminya dengan jalur pengadilan dapat dikatakan dengan Khulu' (dengan memberikan uang tebusan kepada suami) ${ }^{26}$ atau Fasakh ( tanpa tebusan) ${ }^{27}$. Perceraian adalah jalan akhir dari sebuah permasalahan yang terjadi didalam rumah tangga yang tidak kunjung mendapat jalan keluarnya. Dalam islam istri boleh menggugat suaminya didepan pengadilan dengan alasan syar'i yang menjadikan istri berhak mengajukan gugatan perceraian. Misalkan suami tidak bertanggung jawab seperti dalam memberikan nafkah, suami yang tak kunjung pulang atau menghilang dan tidak diketahui dimana keberadaannya selma kurun waktu 2 tahun atau lebih. Seorang istri berhak mengajukan gugatan perceraian atau Khulu' didepan pengadilan agama.

Adapun nash dalam Al-quran yang menjadi dasar dari hukum talak itu sendiri yakni yang mana terdapat didalam QS Al- baqarah: 230 yang berbunyi:

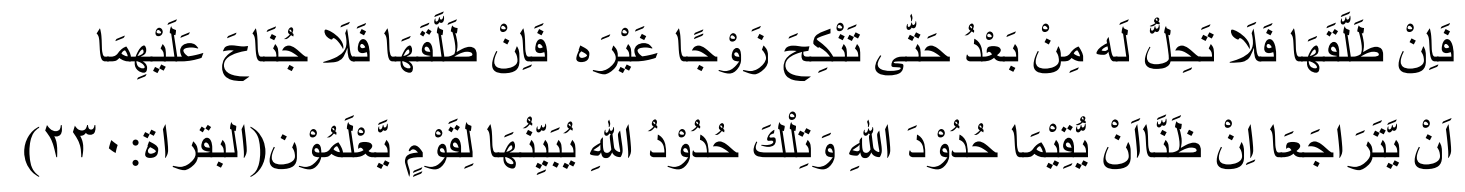

"Kemudian jika dia menceraikannya (setelah talak yang kedua), maka perempuan itu tidak halal lagi baginya sebelum dia menikah dengan suami yang lain. Kemudian jika suami yang lain itu menceraikannya, maka tidak ada dosa bagi keduanya (suami pertama dan bekas istri) untuk menikah kembali jika keduanya berpendapat akan dapat menjalankan hukum-hukum Allah. Itulah ketentuan-ketentuan Allah yang diterangkanNya kepada orang-orang yang berpengetahuan". (AL- baqarah: 230). ${ }^{28}$

Ayat diatas menjelaskan tentang talak, yang mana talak adalah sebuah cara untuk melepaskan ikatan pernikahan dan dan mengakhiri hubungan pernikahan. Perceraian dalam Islam bukan sebuah larangan, akan tetapi sebuah perceraian adalah jalan pintu terkahir dalam sebuah ikatan pernikahan ketika sudah tidak ditemukannya lagi jalam keluar dalam sebuah permasalahan yang terjadi didalam rumah tangga. Perceraian itu sendiri telah diatur dalam pasal 38 huruf b Undangundang pernikahan No. 1 Tahun 1974 tentang perkawinan. Didalam Undang-

\footnotetext{
${ }^{25}$ Ahmad Rofik, Hukum Islam di Indonesia, (Jakarta: Raja Grafindo Persada, 1995).87

${ }^{26} \mathrm{Khulu}^{\prime}$ adalah suatu perceraian yang mana diajukan oleh pihak istri kepada suami yang mana istri memberi tebusan kepada suami agar suami menyetujui terjadinya perceraian.

${ }^{27}$ Fasakh adalah putusnya hubungan pernikahan suami istri didepan pengadilan karena sebab tertentu setelah terjadinya pernikahan, dan fasakh adalah hak suami maupun istri.

28 Departemen Agama RI, Al- Qur'an dan Terjemahannya, Cet.- 10 (Bandung: CV. Diponegoro, 2010).36
} 
undang tersebut dijelaskan bahwa putusnya sebuah perkawanina terjadi dikarenakan adanya kematian, perceraian, dan putusan pengadilan.

Sedangkan dalam pasal 39 Undang- undang perkawinan menjelaskan bahwa perceraian hanya bisa jatuh didepan sidang pengadilan, pasal ini diatur untuk mengatur perkara talak maupun perceraian dalam Islam. Dalam penyebutan perceraian adanya sebutan cerai talak dan cerai gugat, hal ini dimaksudkan untuk membedakan pengertian dari talak tersebut yang mana hal ini disebutkan dalam peraturan pemerintah No. 9 Tahun 1975.29

Pada dasarnya hukum perceraian itu adalah makruh, akan tetapi ada pendapat lain mengenai hukum talak ini, yang mana seperti Ulama Hanabilah (penganut mazhab Hambali) yakni mazhab fikih dalam Islam yang dikemukakan dan dikembangkan oleh Imam Ahmad bin Hambal atau biasa dipanggil dengan sebutan Imam Hambali, beliau memperinci hukum talak ini sendiri yakni:

Talak adakalanya wajib, kadang haran, mubah dan juga kadang dihukumi sunnah tergantung kondisi dan keadaan seseorang tersebut menjatuhkan talak. Talak yang menjadi hukumnya wajib yakni, apabila dalam suatu bahtera rumah tangga suami maupun istri selalu mengalami pertengkaran, dan kedua belah pihak memandang bahwa perceraian adalah jalan terabaik untuk menyelesaikan masalah tersebut dan persengketaan yang terjadi diantara keduanya. Talak wajib termasuk dalam talak orang yang melakukan ila', terhadap istrinya setelah lewat waktu selama empat bulan. ${ }^{30}$

Talak yang di haramkan yakni talak yang dianggap tidak perlu dan tidak ada mengandung unsur alasan yang syar'i untuk menjatuhkan talak. Talak tersebut dihukumi haram karena akan menyebabkan kerugian bagi suami dan istri tersebut. Talak mubah terjadi pada saat diperlukan saja, yang mana dalam talak ini memiliki alasan seperti istri yang terlalu jelek, ataupun sikap istri yang sangat buruk sehingga sang suami tidak dapat melihat kebaikan yang ada pasa sang istri.

Talak mandub atau sunnah, yang mana talak ini dilakukan apabila istri suda tidak bisa ditoleransi, baik dalam sikap dan perbuatan yang membuat suami tidak menyukainya, melalaikan shalat, bersikap tidak sopan dan buruk sehingga suami bisa menjatuhkan talak terhadap istri. Talak adalah hak suami, karena suamilah yang memberi nafkah dalam masa iddah istri, serta suamilah yang bertanggung jawab dalam keadaan rumah tangganya. Selain itu alasan suami yang memegang hak dalam talak adalah karena suami adalah orang yang sabar dalam hal yang tergesah- gesah dengan kata lain tidak mudah memutuskan hal dengan terburuburu walaupn dalam keadaan marah dan ada kesukaran yang terjadi pada dirinya. Sebaliknya dengan wanita, wanita memiliki sikap yang mudah marah, sehingga wanita lebih cepat memutuskan untuk bercerai apabila ia hanya merasa kesal ataupun marah dengan alasan yang tidak jelas. Karena itu kaum wanita tidak diberikan hak dalam menjatuhan talak. ${ }^{31}$

Undang- undang perkawinan No.1 Tahun 1974 membedakan antara perceraian yang diajukan oleh suami dan perceraian yang diajukan oleh istri. Perceraian yang mana tas kemauan suami disebut cerai talak yang mana suamilah

\footnotetext{
${ }^{29}$ Linda Azizah, “Analisis Perceraian Dalam Kompilasi Hukum Islam,” Jurnal Al-'Adalah, Vol. 10. No. 4 (4 Juli 2012):24

30 Tihami dan Sohari Sahrani, Fiqih Munakahat (Jakarta: Raja Pers, 2009).250

31 Tihami dan Sohari Sahrani, Fiqih Munakahat.251
} 
sebagi pemohon dari jatuhnya sebuah perceraian dan istri sebagai termohon, sedangkan perceraian yangdiajukan oleh istri disebut sebagai cerai gugat yang mana istri yang menjadi penggugat dan suami sebagai tergugat. ${ }^{32}$

Perceraian dengan jalan talak menurut Kompilasi Hukum Islam pasal 117 menjelaskan bahwa talak adalah suatu ikrar suami dihadapan sidang Pengadilan Agama yang menjadi salah satu penyebab putusnya perkawinan. ${ }^{33}$ Dalam Undangundang No. 7 tahun 1989 tentang Pengadilan Agama juga menjelaskan hal yang sama yang mana juga terdapat pada Pasal 66 ayat (1) yang berbunyi:

"Seseorang suami yang beragama islam yang akan menceraikan istrinya mengajukan permohonan kepada Pengadilan untuk mengadakan sidang guna menyaksikan ikrar talak."

Perceraian dengan jalan talak dibedakan menjadi 2 bagian yakni talak raj'i dan talak ba'in yang mana secara khusus telah diatur dalan Hukum Islam, dalam hukum Islam talak adalah hak suami untuk menceraikan istrinya. Adapun pembagiannya adalah sebagai berikut; Pertama, talak raj'i. Talak raj'i adalah talak yang mana dijatuhkan oleh suami kepada istrinya yang masih dicampurinya dan istri masih dalam masa iddah. ${ }^{34}$ Dalam hal ini suami memiliki hak untuk merujuk kembali istri yang sudah ia talak baik istri setuju maupun tidak setelah talak itu dijatuhkan dengan lafal- lafal tertentu. Dalam Kompilasi Hukum Islam pasal 118: talak raj'i adalah talak kesatu atau kedua, dimana suami berhak rujuk selama istri dalam masa iddah.

Kedua, talak ba'in. Talak ba'in adalah talak yang memisahkan sama sekali hubungan suami istri yang mana talak ba'in dibagi menjadi dua macam yakni talak ba'in sughra dan talak ba'in kubra. Talak ba'in sughra adalah talak yang mana menghilangkan hak- hak untuk rujuk kembali sebagai suami istri, akan tetapi tidak menghilangkan hak untuk menikah baru kembali kepada istri bekas istrinya itu. ${ }^{35}$ Adapun yang termasuk dalam talak ba'in sughra adalah talak yang dijatuhkan oleh suami kepada istri yang belum terjadi setubuh dan khulu'.

Sedangkan talak ba'in kubra adalah talak yang mengakibatkan hilangnya hak rujuk kepada bekas istri, meskipun dari keduanya menginginkan untuk kembal lagi baik dalam masa iddah maupun setelahnya. Sebagian ulama berpendapat tentang talak ba'in kubra adalah semacam perceraian yang mengandung unsur- unsur sumpah yakni: ila ${ }^{\prime 36}$, zihar ${ }^{37}$, dan li'an $^{38}$.

\footnotetext{
32 A, Mukti Arto, Praktek Perdata pada Pengadian Agama (Yogyakarta: Pustaka Pelajar, 1998).202

33 Hamid Zahri, Pokok- pokok Hukum Perkawinan Dalam Islam dan Undang- undang Perkawinan di Indonesia, (Yogyakarta: Bina Cipta, 1978).46

${ }^{34}$ Djmaan Nur, Fiqih Munakahat, (Semarang: Sinar Baru Algensindo, 2010).373

35 Tihani dan Sohari Sahrani,Fiqih Munakahat (Jakarta: PT Raja Grafindo Persada, 2009).244-245

${ }^{36}$ Ila' $^{\prime}$ adalah sumpah suami, bahwa iia bersumpah tidak akan menggauli istrinya dalam masa yang lebih dari empat bulan atau tidak menyebutkan masa.

${ }^{37}$ Zihar adalah seorang lelaki yang menyempurnakan istrinya dengan ibunya sehingga haram atasnya.

${ }^{38}$ Li'an adalah sumpah suami terhadap istri, yang mana suami bersumpah menuduh istri melakukan zina kepada lelaki lain dan sumpah diucapkan sebanyak 4 kali.
} 


\section{Batasan dan Syarat Talak}

Islam telah menetapkan beberapa batasan dan sejumlah syarat untuk talak, yakni: ${ }^{39}$ Pertama, dari segi individu, ia harus seorang yang baligh, berakal, dan orang yang terpilih karena talak tidak dapat jatuh pada anak kecil, orang gila, orang yang di paksa, dan orang yang mabuk. Kedua, dari segi ucapan, yang mana talak harus di ucapkan secara jelas. Ulama fiqih berpendapat talak tidak jatuh jika pengucapannya tidak jelas dan tidak menggunakan kata- kata talak seperti " $A k u$ talak engkau."

Ketiga, dari segi tujuan. Dalam menjatuhkan talak harus memiliki alasan dan tujuan mengapa menjatuhkan talak, orang- orang yang menjatuhkan talak dalam keadaan tidak sadar seperti mabuk maka talaknya batal. Keempat, dari segi jumlah, yang mana berdasarkan firman Allah dalam QS. Al- Baqarah ayat 229 yang berbunyi:

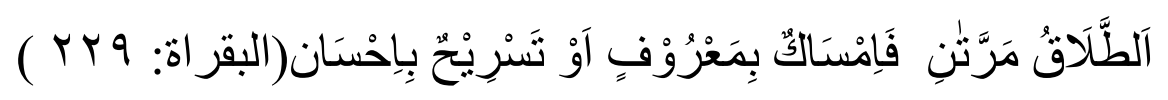

"Talak (yang dapat dirujuki) dua kali. Setelah itu boleh rujuk lagi dengan cara yang makruf'(Al- baqarah: 229).

Kelima, dari segi kesaksian, menurut mayoritas ulama fiqh bahwa kesaksian adalah wajib dalam talak, berdasarkan firman Allah SWT dalam QS. Ath- Thalaq ayat 2:

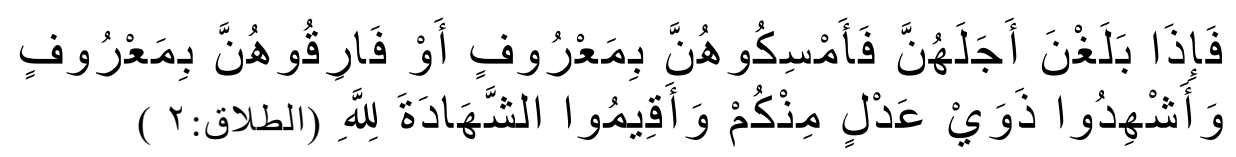

"Apabila mereka telah mendekati akhir iddahnya, maka rujukilah mereka dengan baik atau lepaskanlah mereka dengan baik dan persaksikanlah dengan dua orang saksi yang adil di antara kamu dan hendaklah kamu tegakkan kesaksian itu karena Allah. (At- Thalaq: 2 ).40

Dalam penelitian ini penulis mengangkat masalah tentang faktor dominan perceraian suami perantau di Kec. Sawit Seberang Kab. Langkat dan bagaimana pandangan hukum islam terhadap perceraian yang terjadi di kalangan masyarakat Kec. Sawit Seberang, sehingga dalam hal ini penulis membatsi masalah agar lebih mudah untuk dipahami yang dimaksud tentang perceraian yang sering terjadi dikalangan masyarakat, terutama di Kec. Sawit Seberang Kab. Langkat.

Mengingat banyaknya kasus perceraian yang sering terjadi dikalangan masyarakat, al ini dikarenakan beberapa faktor. Adapun hal-hal yang memicu terjadinya perceraian adalah sebagaimana yang dijelaskan dalam pasal 39 ayat (2) Undang- undang Nomor 1 Tahun 1974 yakni:

a. Suatu pihak melakukan zina, penjudi ataupun seorang pemabuk.

b. Salah satu pihak meninggalkan pihak lain selama dua tahun berturut- turut tanpa izin pihak yang lain.

\footnotetext{
${ }^{39}$ Ali Yusuf As- Subki, Fiqh Keluarga (Jakarta: Amzah, 2010).334

40 Departemen Agama RI, Al-Qur'an dan Terjemahannya.h.558
} 
c. Salah satu pihak mendapat hukuman penjara selama 5 tahun ataupun hukuman berat setelah pernikahan

d. Salah satu pihak melakukan tindak kekerasan dalam rumah tangga

e. Salah satu pihak memiliki kecacatan ataupun penyakit yang mana tidak dapat menjalankan kewajibannya sebagai suami ataupun istri.

f. Dalam kehidupan rumah tangga selal terjadi perselisihan dan pertengkaran yang sudah tidak menjamin keluarga akan rukun kembali. ${ }^{41}$

Dalam Kompilasi Hukum Islam juga menjelaskan hal yang sama tentang alasan perceraian, akan tetapi dalam Kompilasi Hukum Islam terdapat dua poin tambahan dalam penyempurnaannya yang mana hal tersebut terdapat didalam pasal 116 yakni:

g. Suami melanggar taklik talak.

h. Peralihan agama atau murtad yang menyebabkan terjadinya ketidakrukunan dalam rumah tangga. ${ }^{42}$

Pasal di atas menjelaskan bahwa alasan- alasan yang diperbolehkan melakukan perceraian salah satunya adalah melakukan kekejaman atau penganiayaan yang membahayakan salah satu pihak dan adanya perselisihan terus menerus diantara suami istri.

\section{Hubungan Talak dan Harta Bersama}

Munculnya konsepsi harta bersama di kalangan masyarakat, terutama masyarakat Aceh merupakan salah satu bentuk implementasi kemaslahatan, dalam kajian ushul fiqih diatur pada bab maqasid al-syar i atau tujuan-tujuan syari at untuk memenuhi kebutuhan dan kemaslahatan manusia dalam menghadapi kompleksitas hukum yang tidak semuanya diatur secara kodifikasi. Menariknya, dalam teori fiqih klasik konsepsi harta bersama tidak dijumpai secara tegas. Bahkan dalam kitab-kitab mazhab Syafi i sebagai mazhab yang dianut mayoritas masyarakat Aceh tidak menyebutkan secara teks mengenai harta bersama.

Demikian pula hukum Islam klasik yang terangkum dalam kitab fiqih, tidak membicarakan, mengenai: kadar pembagian harta bersama, isteri atau suami nusyuz, isteri atau suami bekerja, atau sama-sama bekerja. Artinya menurut hemat penulis, jika terjadi perceraian atau talak, maka suami hanya diwajibkan untuk membayar mut'ah, nafaqah, biaya pengasuhan anak dan juga membayar mahar yang belum dilunasi (mahar ta jil).

Dalam kajian fiqih yang menjelaskan tentang kewajiban seorang mantan suami tersebut apabila dipahami adalah lahir di negara Arab. Negara tersebut kultur seorang isteri harus di rumah, sedang suami bekerja. Hal ini tentu saja berbeda dengan Indonesia yang mempunyai kultur perempuan dapat bekerja dan berkarir sesuai dengan kemampuannya, bahkan sebagian dari isteri-isteri mendapat penghasilan lebih banyak dari pada suami. Sehingga tidak menutup kemungkinan isteri dapat dikategorikan ke dalam golongan yang berhak atas harta bersama dan mendapat bagian lebih besar sesuai dengan usaha mereka.

\footnotetext{
${ }^{41}$ Ahmad Rofik, Hukum Islam di Indonesia. 87

42 Departemen Agama RI, Kompilasi Hukum Islam (Jakarta: Kompilasi Direktorat Jendral Pembinaan Kelembagaan Agama Islam, 2001).57
} 
Sebuah konsep baru tentang kategorisasi harta bersama dalam Islam menurut Ismail Muhammad Syah sebagaimana dikutip Yahya Harahap mengatakan "pencarian bersama suami isteri mestinya masuk dalam rubu'ul mu'amalah, Tetapi ternyata secara khusus tidak dibicarakan." Lebih lanjut Ismuha berpendapat "mungkin hal ini disebabkan pada umumnya pengarang dari kitabkitab tersebut adalah orang Arab, sedang adat Arab tidak mengenal adanya harta bersama suami isteri. Tetapi yang ada dibicarakan mengenai masalah perkongsian yang dalam bahasa Arab disebut syarikah atau syirkah.

Selanjutnya Ismuha menjelaskan, karena masalah pencarian bersama suami isteri adalah termasuk perkongsian atau syirkah, maka dalam kajian syirkah, maka menurut Ismuha harta bersama masuk pada pembahasan syirkah mufāwadah dan abdān. ${ }^{43}$ Syirkah mufāwadah adalah kesepakatan di antara dua orang atau lebih untuk berserikat dalam hal pekerjaannya saja. ${ }^{44}$ Menurut Hanafiyah syirkah mufāwadah adalah kesepakatan dua orang atau lebih terhadap suatu pekerjaan. ${ }^{45}$ Sedangkan syirkah abdān adalah kesepakatan dua orang untuk saling menerima pekerjaan dari bermacam-macam pekerjaan, agar upah dari pekerjaan tersebut adalah menjadi milik berdua sesuai dengan kesepakatan.

Menurut M. Yahya, para pakar hukum Islam berbeda pendapat mengenai dasar hukum harta bersama. Sebagian mereka mengatakan hukum Islam tidak mengatur tentang harta bersama terutama dalil dari al-Qur'an dan hadits. Sebagian pakar hukum Islam yang lain mengatakan suatu hal yang tidak mungkin jika agama Islam tidak mengatur tentang harta bersama ini, sedangkan hal-hal lain yang kecil saja diatur secara rinci oleh agama Islam dan ditentukan kadar hukumnya. Tidak ada satupun yang tertinggal, semuanya termasuk dalam ruang lingkup pembahasan hukum Islam. Jika tidak disebutkan dalam Al-Qur'an maka disebutkan dalam Hadits. ${ }^{46}$

Mengingat secara tegas harta bersama tidak secara jelas di bahas dalam berbagai literatur klasik, sehingga tidak ada penjelasan hukumnya, maka persoalan harta bersama ini sangat penting untuk dikaji dan diteliti sehingga menemukan hukum dan penyelesaiannya. Pasca perceraian, baik cerai mati atau talak, banyak menimbulkan problema kehidupan sosial masyarakat, terutama dialami oleh anakanak, suami atau isteri, keluarga kedua belah pihak. Dimulai dari terpisahnya anakanak dari kedua orang tuanya, merenggangnya hubungan antar keluarga, sampai kepada perebutan harta benda.

Persoalan yang terjadi di Aceh adalah ketika putus perkawinan karena talak, anggapan dan pemahaman suami isteri tidak berhak mendapat bagian harta bersama. Mengenai kadar bagiannya sebagaimana dalam ilmu faraidh yaitu dua banding satu, atau isteri diberikan hak seadanya, mengingat suami bekerja dan berusaha mencari nafkah seorang diri sementara isteri tinggal dirumah. Pada sisi lain pemahaman isteri mendapatkan hak harta bersama serta menginginkan pembagian harta bersama sebagaimana yang diatur dalam hukum Islam di

\footnotetext{
43Yahya Harahap, Kedudukan Kewenangan Dan Acara Peradilan Agama UU. No. 7 Tahun 1989 (Jakarta. Sinar Grafika 2009).270-271

44 Yahya Harahap, Kedudukan Kewenangan.212

45 Yahya Harahap, Kedudukan Kewenangan.53

46Jafizham, Persentuhan Hukum di Indonesia dengan Hukum Perkawinan Islam (Medan: Mustika,1977).119
} 
Indonesia yaitu Undang-undang, dan KHI yang menjadi rujukan dan pedoman Pengadilan Agama atau Mahkamah Syar iyah, yaitu dibagi sama antara suami dan isteri satu banding satu.

\section{Faktor Perceraian di Masyarakat Sawit Seberang}

Kasus perceraian banyak terjadi di kalangan masyarakat Sawit Seberang, terutama perceraian dari kalangan suami pekerja perantau, hal ini banyak ditemukan banyaknya kasus perceraian didaerah ini, melalui data yang di ambil di Pengadilan Agama Stabat, yang mana pada tahun 2020 terdapat kasus perceraian sebanyak 1.421 kasus dari cerai gugat dan 312 kasus dari cerai talak pertahunnya dan ditahun 2021 ditemukan ada 704 kasus perceraian mulai dari januari hingga maret, dan kasus perceraian yang semakin meningkat ini mayoritasnya dari kalangan pekerja perantau, hal ini yang menjadi tanda tanya, apa sebab maupun faktor sehingga maraknya kasus perceraian ini kerap terjadi dikalangan masyarakat terutama masyarakat Kec. Sawit Seberang.47

Banyak alasan maupun faktor mengapa banyaknya kasus perceraian dikalangan pekerja perantau ini, dan faktor yang telah ditemukan adalah faktor perselingkuhan, faktor ekonomi, pihak lain meninggalkan pihak lainnya tanpa izin, dan tidak adanya lagi kecocokan antara suami dan istri. Faktor diatas terjadi dikarena kurangnya komunikasi karena terhalangnya jarak tersebut, faktor diatas telah diurutkan sesuai faktor perceraian yang banyak terjadi dan hal ini dapat disimpulkan setelah penulis melakukan observasi berupa wawancara dengan masyarakat yang mengalami kejadian itu sendiri supaya penulis dapat melihat hal apa yang memicu terjadinya perceraian.

Kasus perceraian sangat banyak terjadi dikalangan masyarakat terutama di Kecamatan Sawit Seberang, selama dua tahun terakhir ini terdapat 1.724 pasangan yang bercerai di tahun 2020, lalu 704 pasangan yang bercerai di tahun 2021 dari bulan Januari hingga Maret, hal ini membuktikan bahwa masih banyaknya persoalan yang terjadi dalam rumah tangga yang tidak terselesaikan sehingga mengambil jalan keluar yakni dengan bercerai.

Dalam islam perceraian bukanlah hal yang dilarang, akan tetapi sesuatu hal yang sangat dibenci oleh Allah. Menikah adalah sunnah dan ibadah, jadi perceraian adalah suatu hal yang menyedihkan, dimana rumah tangga yang awalnya dibangun diatas janji suci pernikahan harus putus dengan perceraian. Putusnya perkawinan atau perceraian, yang mana berakhirnya hubungan pernikahan antara suami dan istri.48

Islam mengatur keluarga dengan segala perlindungan dan pertanggungjawaban persyariatannya, islam juga mengatur hubungan antara lelaki dan perempuan, begitu juga dengan pernikahan, Islam mengatur segala hal tentang pernikahan, dan Islam juga mengatur tentang talak atau perceraian. Walaupun perceraian itu diperbolehkan, bukan berarti perceraian itu mudah untuk diucapkam dengan sembarang dan dianggap hanya permainan. Hubungan pernikahan bukanlah permainan begitu juga perceraian, meskipun Allah tidak melarang hal itu terjadi, akan tetapi Allah membenci perbuatan tersebut.

\footnotetext{
47 Data ini diperoleh di Kantor Pengadilan Agama Stabat Kab. Langkat

${ }^{48}$ Amir Syarifuddin, Hukum Perkawinan Islam di Indonesia (Jakarta: Kencana, 2006).189
} 
Perceraian yang terjadi dikalangan masyarakat saat ini terutama di Kec. Sawit Seberang, menandakan bahwa masyarakat masih menganggap pernikahan itu adalah sesuatu yang dapat diputuskan dengan mudah, walaupun secara umum hukumnya tidak diharamkan, akan tetapi masyarakat menganggap remeh pernikahan tersebut sehingga mudah memutuskan hubungan pernikahan. ${ }^{49}$

Dari kasus yang sudah dijelaskan tentang perceraian yang terjadi di Kec. Sawit Seberang Kab. Langkat, penulis bertujuan untuk mencari tahu faktor terbesar apa yang menyebabkan banyaknya masyarakat memutuskan untuk bercerai terutama dari kalangan suami perantau, dan setelah diteliti penulis menemukan empat faktor dominan yang menjadi alasan terbesar sering terjadinya kasus perceraian.

\section{Penutup}

Faktor- faktor yang telah peulis rangkum dalam kasus perceraia seuami perantau yakni ada 4 faktor yang mendominan dalam kasus perceraian ini.beberapa faktor itu sendiri yakni, Faktor perselingkuhan, Faktor ekonomi, Pihak lain meninggalkan pihak lainnya tanpa izin, dan Sudah tidak ada lagi kecocokan antara suami dan istri. Menurut hasil wawancara dari masyarakat yang mengalami kasus perceraian itu sendiri, faktor perselingkuhan adalah yang paling banyak terjadi, dan hasil wawancara dari instansi yang ada di Kecamatan Sawit Seberang, mereka juga berpendapat bahwa faktor terbesar dari maraknya kasus perceraian ini adalah faktor perselingkuhan.

Jadi dapat disimpulkan, bahwa faktor terbesar dalam perceraian yang terjadi di masyarakat Kecamatan Sawit Seberang adalah Faktor perselingkuhan.

Pandang hukum Islam terhadap kasus perceraian yang terjadi di kalangan Masayarakat Sawit seberang bahwa perceraian bukanlah hal yang dapat dibenarkan dalam Islam, sebagaimana yang telah dipaparkan sebelumnya dalam hadis maupun ayat Al- qur'an, bahwa perceraian adalah sesuatu yang boleh akan tetapi sangat dibenci oleh Allah. Ikatan janji suci dalam sebuah pernikahan adalah bermaksud untuk mengikat dua insan selama, akan tetapi banyak masyarakat yang kurang memahmi makna dari pernikahan itu sendiri sehingga perceraian sangat mudah diputuskan dan diucapkan.

\section{Daftar Pustaka}

Abdurrahman, 2015, Kompilasi Hukum Islam, CV Akademi Presissindo. Jakarta Abidin Slamet dan A minuddin H, 1999, Fiqh Munakahat 2, Pustaka Setia. Bandung Arto Mukti, A, 1998, Praktek Perdata Pada Pengadilan Agama, Pustaka Pelajar. Yogyakarta.

Azwar Saifuddin, 1998, Metode Penelitian, Pustaka Pelajar. Yogyakarta. Azzam Muhammad Aziz Abdul, 2009, Fikih Munakahat, Amzah: Jakarta. As- Subki Yusuf Ali, 2010, Fiqh Keluarga, AMZAH. Jakarta.

\footnotetext{
${ }^{49}$ Abdul Aziz Muhammad Azzam dan Abdul Wahhab Sayyed Hawwas, Fiqih Munkahat (Jakarta: Amzah, 2009).251
} 
Efendi Satria, 2004, Problematika Hukum Keluarga Islam Kontenporer, Kencana. Jakarta.

Ghazali Rahmat Abdul, 2008, Fiqh Munakahat, Cet. Ke- 3, Kencana. Jakarta.

Linda Azizah, Analisis Perceraian Dalam Kompilasi Hukum Islam, Lampung : Jurnal Al-'Adalah, Vol 10, ( 4 Juli 2012): No. 4

Nur Djmaan, 2010, Fiqih Munakahat, Sinar Baru Algensindo. Semarang.

Rofik Ahmad, 1995, Hukum Islam di Indonesia, Raja Grafindo Persada. Jakarta.

RI Agama Departemen, 2001, Kompilasi Hukum Islam, Kompilasi Direktorat Jendral Pembinaan Kelembagaan Agama Islam. Jakarta.

RI Agama Departemen, 2010, Al- qur'an dan Terjemahan, Cet. Ke- 10, CV. Diponegoro. Bandung.

Sahrani Sohari, Tihami, 2009, Fiqih Munakahat, PT Raja Grafindo Persada. Jakarta.

Sudariadi, Karyawan KUA, Wawancara Pribadi, Sawit Seberang, 11 November 2020.

Suhaila Zulkifli, Jurnal Hukum Kaidah Media dan Informasi Hukum dan Masyarakat, Volume: 18, 3: 16.

Syarifudin Amir,2006, Hukum Keluarga Islam di Indonesia, Kencana: Jakarta

Thalib Sajuti, 1986, Hukum Kekeluargaan Indonesia, UI- Press. Jakarta.

Wirjono Projodikoro, 1951. Hukum Perkawinan di Indonesia, Jakarta: Sumur Bandung.

WJS. Poerwadarminta, 1976. Kamus Umum Bahasa Indonesia, Jakarta: Balai Pustaka.

Yafizham, 1977. Persentuhan Hukum di Indonesia dengan Hukum Perkawinan Islam, Medan: Mustika.

Yahya Abd a-Rahman al-Khatib, 2009. Ahkam al-Mar'ah al-Hamil fi al-Syari ah alIslamiyah, terj. Mujahidin Muhayan, Jakarta: Qisthi Press.

Yahya Harahap, 1975. Hukum Perkawinan Nasional, Medan: Zahir Trading.

Yusdedi, Ketua Majelis Adat Aceh (MAA) Kota Lhokseumawe, Provinsi Aceh.

Yustiloviani, Pengaturan Harta Bersama dalam Perkawinan Poligami, Jurnal Hukum Islam al-Hurriyah, Bukit Tinggi, STAIN Malikussaleh Djamil Djambek, Vol.7 Nomor.2 Juli-Desember 2006.

Yusuf al-Qardhawi, 1997. Membumikan Syari'at Islam, terj. Muhammad Zaki dan Yasir Tajid, Surabaya: Dunia Ilmu.

Yusuf Hamid al-Amin, 1981. al-Maqasid al-'Ammah li al-Syariah al-Islamiyah, alMaghrib: Dar al-Aman.

Zahrani Hamid, 1978, Pokok- Pokok Hukum Perkawinan Dalam Islam dan Undangundang Perkawinan di Indonesia, Bina Cipta. Yogyakarta.

Zuhaili Wahbah, 2010, Fiqih Imam Syafi'i Jilid II, Almahira. Jakarta. 